Main document

Full title:

\title{
Action of cocaine involves depletion of dopaminergic and serotonergic storage vesicles
}

\author{
Short title:
}

\section{Storage vesicles contribute to cocaine action}

Judith R. Homberg ${ }^{1}$, Peter Karel ${ }^{1}$, Francisca Meyer ${ }^{2}$, Kiki Rink ${ }^{1}$, Josephus A. van Hulten², Nick

H.M. van Bakel², Eric L.W. de Mulder ${ }^{3}$, Lucia Caffino ${ }^{4}$, Fabio Fumagalli ${ }^{4}$ Jitske Jansen $^{5}$,

$$
\begin{gathered}
\text { Rosalinde Masereeuw }{ }^{5} \text {, Gerard J.M. Martens }{ }^{2} \text {, Alexander R. Cools }{ }^{3, \dagger} \text {, and } \\
\text { Michel M.M. Verheij }{ }^{1,2,3, *} \text {. }
\end{gathered}
$$

${ }^{1}$ Department of Cognitive Neuroscience, division of Molecular Neurogenetics, Donders Institute for Brain, Cognition and Behaviour, Radboud University Nijmegen Medical Centre, Kapittelweg 29, 6525 EN Nijmegen, the Netherlands.

${ }^{2}$ Department of Molecular Animal Physiology, Radboud Institute for Molecular Life Sciences, Donders Center for Neuroscience, Faculty of Science, Radboud University Nijmegen, Geert Grooteplein Zuid 26-28, 6525 GA Nijmegen, The Netherlands. ${ }^{3}$ Department of Cognitive Neuroscience, division of Psychoneuropharmacology, Donders Institute for Brain, Cognition and Behaviour, Radboud University Nijmegen Medical Centre, Geert Grooteplein Noord 29, 6500 HB Nijmegen, the Netherlands. ${ }^{4}$ Department of Pharmacological and Biomolecular Sciences, Università degli Studi di Milano, Via Balzaretti 9, 20133 Milan, Italy. ${ }^{5}$ Division of Pharmacology, Utrecht Institute for Pharmaceutical Sciences, Utrecht University, Universiteitsweg 99, 3584 CG Utrecht, the Netherlands. ${ }^{\dagger}$ Author deceased.

\footnotetext{
* Please address correspondence and offprint requests to: Michel M.M. Verheij, Department of Cognitive Neuroscience (CNS), Radboud University Nijmegen Medical Centre (Radboudumc), Kapittelweg 29, 6525 EN Nijmegen, P.O. Box 9101, 6500 HB Nijmegen, The Netherlands, Tel: +31-24-3619565, Fax: +31-24-3540044, Email: M.Verheij@cns.umcn.nl and Michel.Verheij@radboudumc.nl.
} 


\section{Main document}

\section{Abstract}

Cocaine is known to increase the extracellular levels of dopamine (DA) and serotonin (5HT) by inhibiting the neuronal reuptake of these monoamines. However, individuals with reduced monoamine reuptake transporter expression do not display a reduction in cocaine intake, suggesting that a mechanism other than inhibition of monoamine reuptake contributes to the rewarding and addictive effects of the psychostimulant. Here we report that cocaine depletes the dopaminergic and serotonergic storage vesicles of the rat nucleus accumbens. This cocaineinduced vesicle depletion gave rise to acute increases in the extracellular levels of DA and 5-HT, which in turn correlated with monoamine-type-specific changes in behavior. Both the neurochemical and behavioral responses to cocaine varied among individual animals, which was not due to individual differences in the reuptake of DA and 5-HT, but rather to individual differences in their vesicular release. Furthermore, we found that reserpine-induced depletion of storage vesicles reduced both short and long access cocaine self-administration, and the degree of reduction was linked to the vesicular storage capacity of the animals. In conclusion, we demonstrate a novel mechanism by which cocaine increases the extracellular concentrations of accumbal DA and 5-HT, namely via release from storage vesicles. Furthermore, individual differences in cocaine-induced vesicular monoamine release shape individual differences in not only the acute behavioral and neurochemical effects of the stimulant, but also in its intake. Thus, intracellular storage vesicles represent an attractive novel drug target to combat psychostimulant addiction.

\section{Keywords} monoamine release; storage vesicle depletion; synaptic vesicle depletion. 


\section{Main document}

\section{Introduction}

Cocaine (COC) is a powerful psychostimulant that produces short-term euphoria and often leads to addiction. Addiction to COC not only destroys lives of users, but also of their relatives. Presently, there are no FDA-approved drugs to treat COC addiction. Dopamine (DA) is well known to mediate COC effects [1-4], but recent evidence suggests that serotonin (5-HT) plays an important role in the neurochemical and behavioral effects of COC as well [5-9]. For instance, COC administration increases whereas COC withdrawal decreases the extracellular levels of both DA and 5-HT in the nucleus accumbens [9-13]. Moreover, in addition to accumbal DA receptors, accumbal 5-HT receptors have been found to mediate COC-induced locomotor activity and COC reward [14-20].

$\mathrm{COC}$ is known to increase extracellular monoamine levels by blocking plasmalemmal monoamine reuptake transporters [21]. However, the behavioral response to and the intake of COC is not reduced in animals and humans that are marked by a reduction of monoamine reuptake transporters [7, 8, 22-26]. In addition, we and others have found that an acute COC challenge still resulted in an increase in the extracellular levels of DA and 5-HT in the nucleus accumbens of animals lacking plasmalemmal DA and 5-HT transporters [9, 27-29]. False neurotransmitter uptake could explain these findings, but it has been shown that COC-induced increases in the accumbal extracellular levels of a particular monoamine (eg DA) are not explained by COCmediated inhibition of another monoamine (eg 5-HT) transporter [30]. These findings suggest that a mechanism other than DA and 5-HT reuptake inhibition may contribute to the rewarding and addictive effects of COC. Interestingly, in 1977 Scheel-Krüger and co-workers have shown that the behavioral response to $\mathrm{COC}$ also depends on the presence of monoaminergic storage vesicles [see 31]. These observations led us to the hypothesis that COC releases DA and 5-HT into the synaptic cleft by depleting presynaptic storage vesicles. 
bioRxiv preprint doi: https://doi.org/10.1101/651505; this version posted May 27, 2019. The copyright holder for this preprint (which was not certified by peer review) is the author/funder. All rights reserved. No reuse allowed without permission.

Main document

In the present study, we have isolated the presynaptic monoaminergic storage vesicles of

53 the rat nucleus accumbens, and measured COC-induced changes in the intra-vesicular as well as

54 extracellular levels of accumbal DA and 5-HT. We show that COC depletes accumbal

55 dopaminergic and serotonergic storage vesicles. Furthermore, we demonstrate that this COC-

56 induced release of vesicular DA and 5-HT correlates with an increase in walking and rearing,

57 respectively, and that individual-specific increases in the extracellular DA and 5-HT response to

$58 \mathrm{COC}$ are due to individual differences in vesicular monoaminergic storage capacity. Finally, we

59 show that depletion of monoaminergic storage vesicles inhibits the voluntary short and long access

60 intake of COC. 


\section{Main document}

\section{Materials and methods}

\section{Rats}

All experiments were performed in adult male Wistar rats, bred at the Central Animal Facility of the Radboud University, Nijmegen, the Netherlands. Given the individual differences in COC-induced vesicle depletion observed during the first experiment, the remaining 3 experiments were performed in High Responder (HR) and Low Responder (LR) to novelty rats, which have previously been found to differ in the expression of vesicular monoamine transporters type 2 (VMAT-2) [32]. All experiments were performed in accordance with institutional, national and international laws and guidelines for animal care and welfare (see National Research Council (NRC) 2003 guidelines). Every effort was made to minimize the number of animals used and their suffering.

\section{Experiment 1}

Unselected rats received a single injection of COC (dose: $45 \mathrm{mg} / \mathrm{kg}$ ) or saline (volume: 1 $\mathrm{ml} / \mathrm{kg}$, i.p.) and walking and rearing behavior was recorded. After $20 \mathrm{~min}$, these rats were sacrificed by decapitation, bilateral punches of nucleus accumbens sections were collected [33, 34], and storage vesicles were isolated by ultracentrifugation according to the protocol of Staal et al., 2000 [35]. Afterwards, the accumbal vesicles were disrupted by osmotic shock and sonication and their content was injected into a High Performance Liquid Chromatography (HPLC) system coupled to an electrochemical detector (ECD) for the separation and quantification of the vesicular levels of DA and 5-HT. 


\section{Main document}

\section{Experiments 2-4}

HR and LR to novelty rats were selected on a novel open field according to procedures previously described by Cools et al., 1990 [36] and the accumbal levels of plasmalemmal DA and 5-HT uptake [for procedures, see 37, 38], in addition to the accumbal total and vesicular levels of DA and 5-HT (for procedures, see above), were measured. A second group of HR and LR rats underwent stereotactic surgery to implant a microdialysis probe into the right nucleus accumbens [see 39]. After recovery, these rats were injected with the vesicle depleting agent reserpine (RES, doses: 1 or $2 \mathrm{mg} / \mathrm{kg}$ ) or its solvent (volume: $1 \mathrm{ml} / \mathrm{kg}$, i.p.), and $24 \mathrm{~h}$ later accumbal levels of extracellular DA and 5-HT were measured using the above-mentioned HPLC-ECD setup. When the RES-induced reduction of the extracellular levels of accumbal DA and 5-HT was stable, the HR and LR rats of the second group were also injected with COC (dose: $15 \mathrm{mg} / \mathrm{kg}$ ) or saline (volume: $1 \mathrm{ml} / \mathrm{kg}$, i.p.), where after the extracellular accumbal levels of these monoamines as well as walking and rearing were measured for an additional period of $120 \mathrm{~min}$. A third, and final, group of HR and LR rats was implanted with a catheter into the right external jugular vein [40] and, after training, COC self-administration $(0.5 \mathrm{mg} / \mathrm{kg} /$ infusion $)$ was performed for daily $1-\mathrm{h}$ (short access) or 6-h (long access) sessions [for details 41, 42]. When the COC intake reached a stable level, rats were also treated with RES (dose: 1 or $2 \mathrm{mg} / \mathrm{kg}$ ) or its solvent (volume: $1 \mathrm{ml} / \mathrm{kg}$, i.p.), where after they were exposed to their corresponding COC self-administration sessions for an additional period of 6 days. 


\section{Main document}

\section{Results}

COC results in vesicular monoamine release that is correlated with changes in walking and rearing behavior

Ultracentrifugation was used to isolate the storage vesicles of the rat nucleus accumbens (see Fig. 1a for location punch needle). These vesicles expressed high levels of various glycosylated forms of VMAT-2 (Fig. 1b). Sonication-induced disruption of these vesicles resulted in the liberation of vesicular DA (one-way ANOVA: sonication effect: (Fig. 1c): $F_{(1,14)}=5.329$, $\mathrm{p}=0.037$ ) and 5-HT (one-way ANOVA: sonication effect: (Fig. 1d): $\mathrm{F}_{(1,14)}=13.187, \mathrm{p}=0.003$ ).

If $\mathrm{COC}$, as suggested in the introduction, releases monoamines from storage vesicles, it is expected that, after COC treatment, DA and 5-HT concentrations inside these vesicles will be reduced. Following a single systemic injection of COC, the amount of DA inside the storage vesicles of the rat nucleus accumbens was indeed reduced by $\sim 35 \%$ (one-way ANOVA: treatment effect (Fig. 1e): $\left.F_{(1,28)}=7.296, p=0.012\right)$. The COC-induced depletion of the serotonergic storage vesicles in the nucleus accumbens was even larger ( $55 \%$; one-way ANOVA: treatment effect (Fig. 1f): $\left.F_{(1,28)}=12.695, p=0.001\right)$.

COC increased both walking (one-way ANOVA: treatment effect (Fig. 1g): $F_{(1,28)}=96.645$, $\mathrm{p}<0.001$ ) and rearing (one-way ANOVA: treatment effect (Fig. 1h): $\mathrm{F}_{(1,28)}=11.834, \mathrm{p}=0.002$ ). COC-induced changes in behavior as well as vesicular monoamine depletion were higly individual-specific (Supplemental Fig. S1). Interestingly, the COC-induced depletion of vesicular DA (Fig. 1e) significantly correlated with the COC-induced increase in walking (Fig. 1i), but not 
bioRxiv preprint doi: https://doi.org/10.1101/651505; this version posted May 27, 2019. The copyright holder for this preprint (which was not certified by peer review) is the author/funder. All rights reserved. No reuse allowed without permission.

Main document

133

134

135

136

137

138

139

140

141

142

143

144

145

146

147

148

149

150

151

152

153

154

155

156

157

rearing (Fig. 1i). In contrast, the COC-induced depletion of vesicular 5-HT (Fig. 1f) significantly correlated with the COC-induced increase in rearing (Fig. 1i), but not walking (Fig. 1i).

\section{Individual differences in vesicular DA and 5-HT levels}

We have previously shown that rats with a high locomotor response (HR) to novelty express more VMAT-2 in their nucleus accumbens when compared to rats with a low locomotor response (LR) to novelty [32]. VMAT-2 is responsible for the transport of both DA and 5-HT into vesicles [43]. We therefore investigated whether animals that differ in their locomotor response to novelty also differ in their dopaminergic and serotonergic storage capacity of the nucleus accumbens.

HR and LR rats were selected on the basis of their locomotor response to a novel open-field (Supplemental Fig. S2a). The average distance travelled in 30 min was $3.493 \pm 191 \mathrm{~cm}$ for LR and $8.643 \pm 373 \mathrm{~cm}$ for HR. The average habituation time (for details, see supplemental Materials and Methods) was $324 \pm 28 \mathrm{~s}$ and $1.340 \pm 66 \mathrm{~s}$ for LR and HR, respectively. The amount of both DA and 5-HT stored inside accumbal storage vesicles was larger in HR than in LR (one-way ANOVA: rat type effect: DA (Supplemental Fig. S2b): $\mathrm{F}_{(1,16)}=6.100, \mathrm{p}=0.025$ and 5-HT (Supplemental Fig. $\left.\mathrm{S} 2 \mathrm{c}): \mathrm{F}_{(1,16)}=8.150, \mathrm{p}=0.011\right)$. These higher levels of vesicular DA and 5-HT in HR than in LR may account for the finding that the total accumbal levels of DA and 5-HT were also higher in HR as compared to LR (one-way ANOVA: rat type effect: DA (Supplemental Fig. S2d): $F_{(1,18)}=6.000$, $\mathrm{p}=0.023$ and 5-HT (Supplemental Fig. S2e): $\left.\mathrm{F}_{(1,18)}=5.606, \mathrm{p}=0.029\right)$. A Pearson's analysis revealed that both the travelled distance and the habituation time, assessed during the open-field selection procedure, positively correlated with the vesicular levels of accumbal DA and 5-HT (Supplemental Fig. S2f), as well as the total accumbal levels of these monoamines (Supplemental Fig. S2f).

\section{Individual differences in DA and 5-HT response to COC}




\section{Main document} accumbens are larger in HR than in LR rats (Supplemental Fig. S2), together with the finding that extracellular levels of these monoamines more strongly in HR than in LR rats. HR (three-way ANOVA: treatment $\mathrm{x}$ time effect: $\mathrm{DA}: \mathrm{F}_{(28,420)}=6.304, \mathrm{p} \leq 0.001$ and 5-HT: $\mathrm{F}_{(28,420)}=35.875, \mathrm{p} \leq 0.001$ ) and in LR (three-way ANOVA: treatment $\mathrm{x}$ time effect: DA: ANOVA: rat type $x$ treatment $x$ time effect: DA (Fig. $2 a): F_{(28,812)}=1.855, p=0.005$ and 5-HT (Fig. 2b): $\left.\mathrm{F}_{(28,812)}=7.069, \mathrm{p} \leq 0.001\right)$. Both the travelled distance and the habituation time, assessed during the open-field selection procedure, positively correlated with the maximum COC-induced increase in accumbal DA and 5-HT (Fig. 2c). and rearing following the administration of $15 \mathrm{mg} / \mathrm{kg} \mathrm{COC} \mathrm{[44].} \mathrm{This} \mathrm{dose} \mathrm{of} \mathrm{COC,} \mathrm{however,} \mathrm{is}$

177 known to increase the number of automatically collected locomotor activity counts more strongly 178 in HR than in LR [45]. Here we found that $15 \mathrm{mg} / \mathrm{kg}$ COC indeed increases the frequency of 179 walking (two-way ANOVA: treatment effect: $\mathrm{F}_{(1,29)}=61.584, \mathrm{p} \leq 0.001$ ) and rearing (two-way 180 ANOVA: treatment effect: $\mathrm{F}_{(1,29)}=48.110, \mathrm{p} \leq 0.001$ ) events more strongly in HR than in LR (two181 way ANOVA: rat type $x$ treatment effect: walking (Fig. 2d) $F_{(1,29)}=4.626, p=0.040$ and rearing 182 (Fig. 2e): $\left.\mathrm{F}_{(1,29)}=5.491, \mathrm{p}=0.026\right)$. The $\mathrm{COC}$-induced increase in walking and rearing correlated 
bioRxiv preprint doi: https://doi.org/10.1101/651505; this version posted May 27, 2019. The copyright holder for this preprint (which was not certified by peer review) is the author/funder. All rights reserved. No reuse allowed without permission.

Main document

183

184

not only with the COC-induced reduction in the intra-vesicular levels of DA and 5-HT (see Fig. 1), but also with the COC-induced increase in the extracellular levels of these monoamines (Fig. 2f).

\section{Monoaminergic storage vesicles control individual differences in DA and 5-HT response to} COC

To study the putative contribution of storage vesicles to the observed individual differences in the COC-induced increase in extracellular DA and 5-HT levels, COC-treated HR and LR rats were pre-treated with the VMAT-2 inhibitor reserpine (RES). After RES treatment, storage vesicles are known to become empty [39, 46-49]. Because accumbal storage vesicles contain more monoamines in HR than in LR (Supplemental Fig. S2), we hypothesized that COC-treated HR are less sensitive to the monoamine-depleting effects of RES than COC-treated LR.

$1 \mathrm{mg} / \mathrm{kg}$ RES reduced baseline levels (Supplemental Fig. S3) and the COC-induced increase in the extracellular levels of DA and 5-HT (three-way ANOVA: treatment $\mathrm{x}$ time effect: DA (Figs. 3a and 3c): $F_{(28,784)}=3.127, p \leq 0.001$ and 5-HT (Figs. $3 b$ and $3 d$ ): $F_{(28,784)}=8.934$, $\mathrm{p} \leq 0.001)$ in both types of rats (three-way ANOVA: rat type $\mathrm{x}$ treatment ( $\mathrm{x}$ time) effect: DA and 5HT: n.s.). However, the finding that COC could still increase accumbal extracellular DA and 5HT levels in HR treated with $1 \mathrm{mg} / \mathrm{kg}$ RES (Figs. 3a and 3b: one sample t-tests vs baseline: $\mathrm{P}<0.05$ ), but not anymore in LR treated with this dose of the vesicle depleting agent (Figs. 3c and 3d: one sample t-tests vs baseline n.s.) confirms our hypothesis that COC-treated HR are less sensitive to RES than COC-treated LR. 
bioRxiv preprint doi: https://doi.org/10.1101/651505; this version posted May 27, 2019. The copyright holder for this preprint (which was not certified by peer review) is the author/funder. All rights reserved. No reuse allowed without permission.

\section{Main document}

with $2 \mathrm{mg} / \mathrm{kg}$ of RES. This higher dose of RES was not tested in LR, because $1 \mathrm{mg} / \mathrm{kg}$ of RES already completely prevented the COC-induced DA and 5-HT increase in these rats (Figs. $3 \mathrm{c}$ and

3d). As expected, $2 \mathrm{mg} / \mathrm{kg}$ RES reduced the COC-induced increase in extracellular DA and 5-HT

(two-way ANOVA: treatment $\mathrm{x}$ time effect: $\mathrm{DA}: \mathrm{F}_{(28,420)}=5.907, \mathrm{p} \leq 0.001$ and 5-HT:

$\mathrm{F}_{(28,420)}=27.878, \mathrm{p} \leq 0.001$ ) more strongly than $1 \mathrm{mg} / \mathrm{kg}$ of the drug (two-way ANOVA: dose $\mathrm{x}$ time effect: DA (Fig. 3a): $F_{(28,420)}=3.976, p \leq 0.001$ and 5-HT (Fig. 3b): $F_{(28,420)}=6.755, p \leq 0.001$ ).

Monoaminergic storage vesicles control individual differences in walking and rearing

The RES-induced reduction in the COC-mediated increase of accumbal DA and 5-HT (Figs.

3a-3d) prompted us to investigate vesicle-depletion-induced changes in COC-mediated behavior.

$1 \mathrm{mg} / \mathrm{kg}$ RES reduced the frequency of COC-induced walking and rearing events (two-way ANOVA: treatment effect: walking (Fig. 3e): $\mathrm{F}_{(1,28)}=14.818, \mathrm{p}=0.001$ and rearing (Fig. 3f): $\mathrm{F}_{(1,28)}=11.513, \mathrm{p}=0.002$ ) in both HR and LR rats (two-way ANOVA: rat type $\mathrm{x}$ treatment effect: walking and rearing: n.s.). Interestingly, the RES-induced reduction in the COC-induced extracellular DA increase (Fig. 3a) correlated with a decrease in walking (Fig. 3g), but not rearing (Fig. 3g). In contrast, the RES-induced reduction in the COC-induced extracellular accumbal 5HT increase (Fig. 3b) correlated with a decrease in rearing (Fig. 3g), but not walking (Fig. 3g).

The additional HR group of rats pre-treated with $2 \mathrm{mg} / \mathrm{kg}$ RES (see above) was also used to establish the putative dose-response relationship for the vesicle-depletion-induced regulation of 
bioRxiv preprint doi: https://doi.org/10.1101/651505; this version posted May 27, 2019. The copyright holder for this preprint (which was not certified by peer review) is the author/funder. All rights reserved. No reuse allowed without permission.

\section{Main document}

$\mathrm{p}=0.001$ ) more strongly than $1 \mathrm{mg} / \mathrm{kg}$ of the drug (one-way ANOVA: dose effect: walking (Fig.

3e): $F_{(1,15)}=5.676, p=0.030$ and rearing (Fig. 3f): $F_{(1,15)}=5.263, p=0.036$ ).

Reuptake of DA and 5-HT does not control individual differences in response to COC

The results reported above indicate that individual differences in the monoaminergic storage capacity of the nucleus accumbens contribute to individual differences in the behavioral and extracellular monoamine response to COC. Behavioral and neurochemical responses to COC have also been found to depend on plasmalemmal monoamine re-uptake transporters [50]. In addition, changes in neuronal monoamine re-uptake may contribute to changes in novelty-induced exploration [51]. Therefore, individual differences in the re-uptake of DA and 5-HT by the plasmalemmal dopamine or serotonin transporters (DAT or SERT) may also have contributed to the reported results. To explore this possibility, the neuronal DA and 5-HT uptake was investigated neuronal DA and 5-HT uptake in the nucleus accumbens was concentration dependent (two-way

ANOVA: concentration effect: DA: $F_{(5,105)}=118.100, p \leq 0.001$ and 5-HT: $F_{(5,105)}=268.831$, $\mathrm{p} \leq 0.001$ ), but not different between HR and LR rats (two-way ANOVA: rat type (x concentration) effect: DA (Supplemental Fig. S4a): n.s. and 5-HT (Supplemental Fig. S4b): n.s.).

\section{Individual differences in COC self-administration} observed after forced exposure to COC (Fig. 2) suggests that HR and LR also differ in the 
bioRxiv preprint doi: https://doi.org/10.1101/651505; this version posted May 27, 2019. The copyright holder for this preprint (which was not certified by peer review) is the author/funder. All rights reserved. No reuse allowed without permission.

\section{Main document}

during 1 or 6 hour(s) sessions [8, 40-42]. In contrast to short access (ShA: 1 hour per session) COC self-administration, long access (LgA: 6 hours per session) COC self-administration resulted in an escalation of the drug intake over time (three-way ANOVA: access x time effect (Fig. 4a): $\mathrm{F}_{(14,224)}=3.543, \mathrm{p}<0.001$; time effect: $\operatorname{LgA}: \mathrm{F}_{(14,112)}=4.286, \mathrm{p}<0.001$ and ShA: n.s.). The $\operatorname{LgA}$, but not ShA, COC intake was higher in HR than in LR rats (three-way ANOVA: rat type $\mathrm{x}$ access $\mathrm{x}$ time effect: $n . s$; rat type $\mathrm{x}$ access effect: $\mathrm{F}_{(1,16)}=5.450, \mathrm{p}<0.05$; rat type effect: $\operatorname{LgA}: \mathrm{F}_{(1,8)}=5.391$, $\mathrm{p}<0.05$ and ShA: n.s.). In addition, COC intake correlated with the locomotor response to novelty (Fig. 4b).

\section{Monoaminergic storage vesicles control individual differences in COC self-administration}

The observed RES-induced reduction in the COC-mediated increase of extracellular DA and 5-HT in the nucleus accumbens (Fig. 3) prompted us to investigate whether RES-induced depletion of monoaminergic storage vesicles also affects the COC intake in HR and LR rats. Since LR rats were marked by a smaller RES-sensitive monoaminergic storage capacity than HR rats (Supplemental Fig. S2), COC intake was hypothesized to be reduced by RES more strongly in LR than in HR rats. $1 \mathrm{mg} / \mathrm{kg}$ RES did not affect ShA COC self-administration (three way ANOVA: treatment (x time) effect (Figs. 5a and 5b): n.s.). However, the relatively low dose of RES reduced COC self-administration under LgA conditions (three-way ANOVA: treatment x time effect: n.s; treatment effect (Figs. 5c and 5d): $F_{(1,16)}=10.016, p<0.01$ ). As hypothesized, LR rats were more sensitive to the RES-induced reduction in COC intake than HR rats (two-way ANOVA: rat type $\mathrm{x}$ treatment effect: ShA (Fig. 5e): n.s. and LgA (Fig. 5f): $F_{(1,16)}=5.248, p<0.05$ ). In LgA rats, the maximum RES-induced decrease in COC intake (Fig. 5f) was negatively correlated with the locomotor response to novelty (Fig. 5g). No correlation was found between the locomotor response 
bioRxiv preprint doi: https://doi.org/10.1101/651505; this version posted May 27, 2019. The copyright holder for this preprint (which was not certified by peer review) is the author/funder. All rights reserved. No reuse allowed without permission.

Main document

281 to novelty and the COC intake after applying $1 \mathrm{mg} / \mathrm{kg}$ RES to ShA rats (Fig. $5 \mathrm{~g}$ ), possibly because 282 in these rats this dose of RES did not affect psychostimulant intake (Fig. 5e).

To test whether the effects of RES on COC self-administration were dose dependent, a new 285 group of COC-treated HR was pre-treated with $2 \mathrm{mg} / \mathrm{kg}$ of the vesicle depleting agent (see also 286 Fig. 3). As expected, $2 \mathrm{mg} / \mathrm{kg}$ RES reduced the COC intake under both access conditions (two287 way ANOVA: treatment $x$ time effect: ShA (Fig. 5a): $F_{(9,72)}=3.218, p \leq 0.01$ and LgA (Fig. 5c): $\left.288 \mathrm{~F}_{(9,72)}=4.076, \mathrm{p} \leq 0.001\right)$ more strongly than $1 \mathrm{mg} / \mathrm{kg}$ of the drug (one-way ANOVA: dose effect: 289 ShA (Fig. 5e): $\mathrm{F}_{(1,8)}=7.888, \mathrm{p} \leq 0.05$ and LgA (Fig. 5f): $\left.\mathrm{F}_{(1,8)}=8.066, \mathrm{p} \leq 0.05\right)$. 


\section{Main document}

\section{Discussion}

COC depletes monoaminergic storage vesicles

Our data confirm our hypothesis and demonstrate that systemic administration of COC

depletes VMAT-2-containing dopaminergic and serotonergic storage vesicles in the nucleus accumbens of the rat. The finding that RES-induced depletion of these storage vesicles prior to the administration of COC significantly reduced the COC-induced increases in the extracellular levels of accumbal DA and 5-HT, as well as COC-mediated walking and rearing, shows that COCinduced vesicle depletion results in an increase of neurotransmitters in the synaptic cleft. Under the condition that $\mathrm{COC}$ depletes presynaptic storage vesicles, replenishment of these vesicles is required. Indeed, enhanced VMAT-2-dependent monoamine uptake has previously been reported directly following the COC-induced extracellular monoamine peak [52, 53]. Importantly, based also $\mathrm{Ca}^{2+}$ and synapsin, dependent [54-56].

Dopaminergic and serotonergic storage vesicles regulate the neurochemical response

We found that COC increased the accumbal extracellular DA and 5-HT levels more strongly in HR than in LR rats. Although COC has previously been shown to inhibit the reuptake 311 of monoamines by blocking plasmalemmal DA and 5-HT transporters, the finding that HR and 312 LR rats did not differ in the cellular uptake of DA and 5-HT indicates that the observed individual 313 differences in the extracellular accumbal DA and 5-HT response to COC cannot be attributed to 314 individual differences in accumbal plasmalemmal DA and 5-HT transport. In fact, the results 
bioRxiv preprint doi: https://doi.org/10.1101/651505; this version posted May 27, 2019. The copyright holder for this preprint (which was not certified by peer review) is the author/funder. All rights reserved. No reuse allowed without permission.

\section{Main document}

obtained in RES-treated HR and LR suggest that the individual-specific extracellular DA and 5-

316 HT response to COC is mediated by release from storage vesicles. The observed larger dopaminergic and serotonergic storage capacity in the nucleus accumbens of HR compared to LR is in line with the fact that COC could still increase the extracellular accumbal DA and 5-HT levels in HR, but not in LR pre-treated with $1 \mathrm{mg} / \mathrm{kg}$ RES (see Supplemental Fig. S5). Accordingly, we conclude that COC leads to a stronger extracellular increase in DA and 5-HT in the nucleus accumbens of HR than of LR, because COC releases more DA and 5-HT from accumbal storage vesicles in HR than in LR (see Supplemental Fig. S5).

Dopaminergic and serotonergic storage vesicles regulate behavioral response variation to

Our data not only support the generally accepted notion that accumbal DA regulates COCinduced walking [for review 57], but also suggest that COC-induced rearing is regulated by accumbal 5-HT. On the basis of the behavioral effects of RES, we hypothesize that the stronger rearing response to $\mathrm{COC}$ in $\mathrm{HR}$ than in LR is due to a larger COC-induced release of vesicular 5-

331 HT in the nucleus accumbens of HR than of LR. Based on the neurochemical studies of Parsons and Justice [e.g. 58], it has frequently been suggested that the behavioral effects of accumbal 5HT are due to 5-HT-receptor-mediated changes in the local release of DA [59, 60]. Our data not only indicate that accumbal 5-HT mediates rearing independently of changes in accumbal DA, but also that accumbal DA mediates walking behavior independently of changes in accumbal 5-HT.

336 We hypothesize that the stronger walking response to COC in HR than in LR is due to a stronger COC-induced release of vesicular DA in the nucleus accumbens of HR than of LR. 


\section{Main document}

The finding that $2 \mathrm{mg} / \mathrm{kg}$ RES reduced the ShA self-administration of COC, in addition to

342 the finding that both 1 and $2 \mathrm{mg} / \mathrm{kg}$ RES reduced COC self-administration under LgA conditions,

343 indicates that monoaminergic storage vesicles do not only control the COC-induced increase in

344 the extracellular levels of accumbal DA and 5-HT, but also the voluntary intake of the 345 psychostimulant. $1 \mathrm{mg} / \mathrm{kg}$ RES did not affect the ShA intake of COC, showing that the reduction 346 in either COC intake, or in COC-induced walking and rearing, following RES-induced vesicle 347 depletion does not result from motor impairment. The access-specific effect of $1 \mathrm{mg} / \mathrm{kg}$ RES also 348 suggests that COC releases more monoamines from storage vesicles under LgA than under ShA 349 conditions. This is in line with the observed faster recovery of the daily COC intake in ShA versus $350 \mathrm{LgA}$ rats treated with $2 \mathrm{mg} / \mathrm{kg}$ of the vesicle depleting agent.

Storage vesicles control the individual-specific intake of $\mathrm{COC}$

The positive correlation between locomotor response to novelty and COC selfadministration is in line with the higher voluntary intake of this psychostimulant in HR than in LR not only to the stronger COC-induced increase in the extracellular levels of these monoamines,

359 but also to the larger LgA intake of COC in HR than in LR. Not only the neurochemical and 360 locomotor responses to COC, but also to high doses of amphetamine are dependent on the amount 361 of monoamines inside storage vesicles [for refs 39, 57]. This indicates that the previously observed 362 stronger locomotor response to amphetamine and the higher intake of this drug in HR than in LR 363 [67-71] may also have resulted from a stronger amphetamine-induced release of DA and/or 5-HT 364 from accumbal storage vesicles in HR than in LR. Intrestingly, the fact that $1 \mathrm{mg} / \mathrm{kg}$ RES did not 365 affect the ShA intake of COC in both HR and LR, whereas this dose of the vesicle depleter was 366 shown to strongly reduce the extracellular increase of accumbal monoamines in these rats, suggests 
bioRxiv preprint doi: https://doi.org/10.1101/651505; this version posted May 27, 2019. The copyright holder for this preprint (which was not certified by peer review) is the author/funder. All rights reserved. No reuse allowed without permission.

\section{Main document}

that a mode of action different from an increase of extracellular DA and 5-HT in the nucleus accumbens may contribute to the rewarding effects of ShA exposure to cocaine. It remains to be investigated if this novel mode of action involves different neurotransmitters and/or changes in different brain regions.

Storage vesicles may control the effects of $\mathrm{COC}$ in individuals lacking plasmalemmal

transporters

Our finding that, apart from affecting plasmalemmal monoamine transporters, COC is able to increase extracellular monoamine levels may very well explain the previously reported unexpected intake of and behavioral response to $\mathrm{COC}$ in rodents lacking the plasmalemmal transporters $[7,8,25,26]$. Such a monoamine-releasing action of COC may also explain why a reduction in plasmalemmal transporter gene expression does not eliminate the intake of COC by

\section{Conclusions}

accumbal DA and 5-HT by depleting presynaptic storage vesicles, and that individual differences in the response to COC are mediated by individual differences in monoaminergic storage capacity. 
bioRxiv preprint doi: https://doi.org/10.1101/651505; this version posted May 27, 2019. The copyright holder for this preprint (which was not certified by peer review) is the author/funder. All rights reserved. No reuse allowed without permission.

\section{Main document}

392 together with the generally accepted notion that accumbal DA mediates reward [1-4] suggests that 393 RES reduced COC intake by interfering with the reinforcing properties of the psychostimulant. 394 Given that extracellular 5-HT may also modulate reward [15, 20, 75, 76], future studies should 395 focus not only on the manipulation of dopaminergic, but also of serotonergic storage vesicles as a 396 potential therapy to inhibit the intake of COC. 
bioRxiv preprint doi: https://doi.org/10.1101/651505; this version posted May 27, 2019. The copyright holder for this preprint (which was not certified by peer review) is the author/funder. All rights reserved. No reuse allowed without permission.

\section{Main document}

\section{Acknowledgements}

398

The authors wish to thank Benito Willemsen and Sandra van de Wiel for technical

400 assistance and Dr. Dick Heeren for advice on statistical analysis of the data. MV and JH were

401 supported by a joint program of the Netherlands Organization for Health Research and 402 Development (ZonMW) and the USA National Institute for Drug Abuse (NIDA), project no. 403 31180005. MV is also supported by an ECNP research grant for young scientists and a NIDA 404 INVEST Drug Abuse Research Fellowship. FF and LC were supported by grants from MIUR 405 Progetto Eccellenza. The authors declare no conflict of interest. 


\section{Main document}

\section{References}

1. Koob, G.F. (1996). Hedonic valence, dopamine and motivation. Mol Psychiatry 1, 186189.

2. Volkow, N.D., and Morales, M. (2015). The Brain on Drugs: From Reward to Addiction. Cell 162, 712-725.

3. Koob, G.F., and Volkow, N.D. (2016). Neurobiology of addiction: a neurocircuitry analysis. Lancet Psychiatry 3, 760-773.

4. Volkow, N.D., Koob, G.F., and McLellan, A.T. (2016). Neurobiologic Advances from the Brain Disease Model of Addiction. N Engl J Med 374, 363-371.

5. Filip, M., Alenina, N., Bader, M., and Przegalinski, E. (2010). Behavioral evidence for the significance of serotoninergic (5-HT) receptors in cocaine addiction. Addict Biol 15, $227-$ 249.

6. Nonkes, L.J., van Bussel, I.P., Verheij, M.M., and Homberg, J.R. (2011). The interplay between brain 5-hydroxytryptamine levels and cocaine addiction. Behav Pharmacol 22, 723-738.

7. Homberg, J.R., De Boer, S.F., Raaso, H.S., Olivier, J.D., Verheul, M., Ronken, E., Cools, A.R., Ellenbroek, B.A., Schoffelmeer, A.N., Vanderschuren, L.J., et al. (2008). Adaptations in pre- and postsynaptic 5-HT1A receptor function and cocaine supersensitivity in serotonin transporter knockout rats. Psychopharmacology (Berl) 200, 367-380.

8. Verheij, M.M.M., Contet, C., Karel, P., Latour, J., van der Doelen, R.H.A., Geenen, B., van Hulten, J.A., Meyer, F., Kozicz, T., George, O., et al. (2018). Median and Dorsal Raphe Serotonergic Neurons Control Moderate Versus Compulsive Cocaine Intake. Biol Psychiatry 83, 1024-1035.

9. Verheij, M.M., Karel, P., Cools, A.R., and Homberg, J.R. (2014). Reduced cocaineinduced serotonin, but not dopamine and noradrenaline, release in rats with a genetic deletion of serotonin transporters. Eur Neuropsychopharmacol 24, 1850-1854.

10. Andrews, C.M., and Lucki, I. (2001). Effects of cocaine on extracellular dopamine and serotonin levels in the nucleus accumbens. Psychopharmacology (Berl) 155, 221-229.

11. Teneud, L.M., Baptista, T., Murzi, E., Hoebel, B.G., and Hernandez, L. (1996). Systemic and local cocaine increase extracellular serotonin in the nucleus accumbens. Pharmacol Biochem Behav 53, 747-752.

12. Parsons, L.H., Koob, G.F., and Weiss, F. (1995). Serotonin dysfunction in the nucleus accumbens of rats during withdrawal after unlimited access to intravenous cocaine. $\mathrm{J}$ Pharmacol Exp Ther 274, 1182-1191.

13. Parsons, L.H., Koob, G.F., and Weiss, F. (1996). Extracellular serotonin is decreased in the nucleus accumbens during withdrawal from cocaine self-administration. Behav Brain Res 73, 225-228. 


\section{Main document}

14. Herges, S., and Taylor, D.A. (2000). Involvement of 5-HT(3) receptors in the nucleus accumbens in the potentiation of cocaine-induced behaviours in the rat. Br J Pharmacol 131, 1294-1302.

15. Filip, M., and Cunningham, K.A. (2002). Serotonin 5-HT(2C) receptors in nucleus accumbens regulate expression of the hyperlocomotive and discriminative stimulus effects of cocaine. Pharmacol Biochem Behav 71, 745-756.

16. Przegalinski, E., Filip, M., Papla, I., and Czepiel, K. (2002). Effects of 5-HT1B receptor ligands microinjected into the accumbal shell or core on the cocaine-induced locomotor hyperactivity in rats. J Physiol Pharmacol 53, 383-394.

17. McMahon, L.R., Filip, M., and Cunningham, K.A. (2001). Differential regulation of the mesoaccumbens circuit by serotonin 5-hydroxytryptamine (5-HT)2A and 5-HT2C receptors. J Neurosci 21, 7781-7787.

18. Ferguson, S.M., Mitchell, E.S., and Neumaier, J.F. (2008). Increased expression of 5-HT6 receptors in the nucleus accumbens blocks the rewarding but not psychomotor activating properties of cocaine. Biol Psychiatry 63, 207-213.

19. Katsidoni, V., Apazoglou, K., and Panagis, G. (2011). Role of serotonin 5-HT2A and 5HT2C receptors on brain stimulation reward and the reward-facilitating effect of cocaine. Psychopharmacology (Berl) 213, 337-354.

20. Filip, M., Papla, I., Nowak, E., Jungersmith, K., and Przegalinski, E. (2002). Effects of serotonin $(5-\mathrm{HT})(1 \mathrm{~B})$ receptor ligands, microinjected into accumbens subregions, on cocaine discrimination in rats. Naunyn Schmiedebergs Arch Pharmacol 366, 226-234.

21. Han, D.D., and Gu, H.H. (2006). Comparison of the monoamine transporters from human and mouse in their sensitivities to psychostimulant drugs. BMC Pharmacol 6, 6.

22. Enoch, M.A., Gorodetsky, E., Hodgkinson, C., Roy, A., and Goldman, D. (2011). Functional genetic variants that increase synaptic serotonin and 5-HT3 receptor sensitivity predict alcohol and drug dependence. Mol Psychiatry 16, 1139-1146.

23. Gerra, G., Zaimovic, A., Garofano, L., Ciusa, F., Moi, G., Avanzini, P., Talarico, E., Gardini, F., Brambilla, F., Manfredini, M., et al. (2007). Perceived parenting behavior in the childhood of cocaine users: relationship with genotype and personality traits. Am $\mathbf{J}$ Med Genet 144B, 52-57.

24. Guindalini, C., Howard, M., Haddley, K., Laranjeira, R., Collier, D., Ammar, N., Craig, I., O'Gara, C., Bubb, V.J., Greenwood, T., et al. (2006). A dopamine transporter gene functional variant associated with cocaine abuse in a Brazilian sample. Proc Natl Acad Sci USA $103,4552-4557$.

25. Rocha, B.A., Fumagalli, F., Gainetdinov, R.R., Jones, S.R., Ator, R., Giros, B., Miller, G.W., and Caron, M.G. (1998). Cocaine self-administration in dopamine-transporter knockout mice. Nat Neurosci 1, 132-137.

26. Sora, I., Wichems, C., Takahashi, N., Li, X.F., Zeng, Z., Revay, R., Lesch, K.P., Murphy, D.L., and Uhl, G.R. (1998). Cocaine reward models: conditioned place preference can be 


\section{Main document}

established in dopamine- and in serotonin-transporter knockout mice. Proc Natl Acad Sci USA 95, 7699-7704.

27. Carboni, E., Spielewoy, C., Vacca, C., Nosten-Bertrand, M., Giros, B., and Di Chiara, G. (2001). Cocaine and amphetamine increase extracellular dopamine in the nucleus accumbens of mice lacking the dopamine transporter gene. J Neurosci. 21, RC141-RC144.

28. Sora, I., Hall, F.S., Andrews, A.M., Itokawa, M., Li, X.F., Wei, H.B., Wichems, C., Lesch, K.P., Murphy, D.L., and Uhl, G.R. (2001). Molecular mechanisms of cocaine reward: combined dopamine and serotonin transporter knockouts eliminate cocaine place preference. Proc Natl Acad Sci USA 98, 5300-5305.

29. Gainetdinov, R.R., Sotnikova, T.D., and Caron, M.G. (2002). Monoamine transporter pharmacology and mutant mice. Trends Pharmacol Sci 23, 367-373.

30. Mateo, Y., Budygin, E.A., John, C.E., Banks, M.L., and Jones, S.R. (2004). Voltammetric assessment of dopamine clearance in the absence of the dopamine transporter: no contribution of other transporters in core or shell of nucleus accumbens. J Neurosci Meth $140,183-187$.

31. Scheel-Krüger, J., Braestrup, C., Nielson, M., Golembiowska, K., and Mogilnicka, E. (1977). Cocaine: discussion on the role of dopamine in the biochemical mechanism of action. In: Advances in behavioral biology, Volume 1, E.H. Ellinwood Jr and M.M. Kilbey, eds. (New York: Plenum press), pp. 373-407.

32. Verheij, M.M., de Mulder, E.L., De Leonibus, E., van Loo, K.M., and Cools, A.R. (2008). Rats that differentially respond to cocaine differ in their dopaminergic storage capacity of the nucleus accumbens. J Neurochem 105, 2122-2133.

33. Mong, J.A., Devidze, N., Frail, D.E., O'Connor, L.T., Samuel, M., Choleris, E., Ogawa, S., and Pfaff, D.W. (2003). Estradiol differentially regulates lipocalin-type prostaglandin D synthase transcript levels in the rodent brain: Evidence from high-density oligonucleotide arrays and in situ hybridization. Proc Natl Acad Sci USA 100, 318-323.

34. Szczypka, M.S., Kwok, K., Brot, M.D., Marck, B.T., Matsumoto, A.M., Donahue, B.A., and Palmiter, R.D. (2001). Dopamine production in the caudate putamen restores feeding in dopamine-deficient mice. Neuron 30, 819-828.

35. Staal, R.G., Hogan, K.A., Liang, C.L., German, D.C., and Sonsalla, P.K. (2000). In vitro studies of striatal vesicles containing the vesicular monoamine transporter (VMAT2): rat versus mouse differences in sequestration of 1-methyl-4-phenylpyridinium. J Pharmacol Exp Ther 293, 329-335.

36. Cools, A.R., Brachten, R., Heeren, D., Willemen, A., and Ellenbroek, B. (1990). Search after neurobiological profile of individual-specific features of Wistar rats. Brain Res Bull 24, 49-69.

37. Izenwasser, S., Werling, L.L., and Cox, B.M. (1990). Comparison of the effects of cocaine and other inhibitors of dopamine uptake in rat striatum, nucleus accumbens, olfactory tubercle, and medial prefrontal cortex. Brain Res 520, 303-309. 


\section{Main document}

38. Pollier, F., Sarre, S., Aguerre, S., Ebinger, G., Mormede, P., Michotte, Y., and Chaouloff, F. (2000). Serotonin reuptake inhibition by citalopram in rat strains differing for their emotionality. Neuropsychopharmacology 22, 64-76.

39. Verheij, M.M., and Cools, A.R. (2007). Differential contribution of storage pools to the extracellular amount of accumbal dopamine in high and low responders to novelty: effects of reserpine. J Neurochem 100, 810-821.

40. Wee, S., Specio, S.E., and Koob, G.F. (2007). Effects of dose and session duration on cocaine self-administration in rats. J Pharmacol Exp Ther 320, 1134-1143.

41. Ahmed, S.H., and Koob, G.F. (1998). Transition from moderate to excessive drug intake: change in hedonic set point. Science 282, 298-300.

42. Verheij, M.M., Vendruscolo, L.F., Caffino, L., Giannotti, G., Cazorla, M., Fumagalli, F., Riva, M.A., Homberg, J.R., Koob, G.F., and Contet, C. (2016). Systemic Delivery of a Brain-Penetrant TrkB Antagonist Reduces Cocaine Self-Administration and Normalizes TrkB Signaling in the Nucleus Accumbens and Prefrontal Cortex. J Neurosci 36, 81498159 .

43. Bernstein, A.I., Stout, K.A., and Miller, G.W. (2014). The vesicular monoamine transporter 2: an underexplored pharmacological target. Neurochem Int 73, 89-97.

44. Verheij, M.M., and Cools, A.R. (2011). Reserpine differentially affects cocaine-induced behavior in low and high responders to novelty. Pharmacol Biochem Behav 98, 43-53.

45. Hooks, M.S., Jones, G.H., Smith, A.D., Neill, D.B., and Justice, J.B., Jr. (1991). Response to novelty predicts the locomotor and nucleus accumbens dopamine response to cocaine. Synapse 9, 121-128.

46. Bruns, D., Riedel, D., Klingauf, J., and Jahn, R. (2000). Quantal release of serotonin. Neuron 28, 205-220.

47. Colliver, T.L., Pyott, S.J., Achalabun, M., and Ewing, A.G. (2000). VMAT-Mediated changes in quantal size and vesicular volume. J Neurosci 20, 5276-5282.

48. Gong, L.W., Hafez, I., Alvarez-de-Toledo, G., and Lindau, M. (2003). Secretory vesicles membrane area is regulated in tandem with quantal size in chromaffin cells. J Neurosci 23, 7917-7921.

49. Michalke, W., Langer, R., and Burger, A. (1990). Ghosts of chromaffin granules accumulate biogenic amines according to a "pump and leak system" without contribution of carrier-mediated efflux. Naunyn Schmiedebergs Arch Pharmacol 342, 312-322.

50. Giros, B., Jaber, M., Jones, S.R., Wightman, R.M., and Caron, M.G. (1996). Hyperlocomotion and indifference to cocaine and amphetamine in mice lacking the dopamine transporter. Nature 379, 606-612.

51. Leo, D., Sukhanov, I., Zoratto, F., Illiano, P., Caffino, L., Sanna, F., Messa, G., Emanuele, M., Esposito, A., Dorofeikova, M., et al. (2018). Pronounced Hyperactivity, Cognitive Dysfunctions, and BDNF Dysregulation in Dopamine Transporter Knock-out Rats. J Neurosci 38, 1959-1972. 


\section{Main document}

52. Brown, J.M., Hanson, G.R., and Fleckenstein, A.E. (2001). Regulation of the vesicular monoamine transporter-2: a novel mechanism for cocaine and other psychostimulants. $\mathrm{J}$ Pharmacol Exp Ther 296, 762-767.

53. Brown, J.M., Hanson, G.R., and Fleckenstein, A.E. (2001). Cocaine-induced increases in vesicular dopamine uptake: role of dopamine receptors. J Pharmacol Exp Ther 298, 11501153.

54. Hurd, Y.L., and Ungerstedt, U. (1989). Cocaine: an in vivo microdialysis evaluation of its acute action on dopamine transmission in rat striatum. Synapse 3, 48-54.

55. Venton, B.J., Seipel, A.T., Phillips, P.E., Wetsel, W.C., Gitler, D., Greengard, P., Augustine, G.J., and Wightman, R.M. (2006). Cocaine increases dopamine release by mobilization of a synapsin-dependent reserve pool. J Neurosci 26, 3206-3209.

56. Wang, Y.M., Gainetdinov, R.R., Fumagalli, F., Xu, F., Jones, S.R., Bock, C.B., Miller, G.W., Wightman, R.M., and Caron, M.G. (1997). Knockout of the vesicular monoamine transporter 2 gene results in neonatal death and supersensitivity to cocaine and amphetamine. Neuron 19, 1285-1296.

57. Verheij, M.M., and Cools, A.R. (2008). Twenty years of dopamine research: individual differences in the response of accumbal dopamine to environmental and pharmacological challenges. Eur J Pharmacol 585, 228-244.

58. Parsons, L.H., and Justice, J.B., Jr. (1993). Perfusate serotonin increases extracellular dopamine in the nucleus accumbens as measured by in vivo microdialysis. Brain Res 606 , 195-199.

59. Bubar, M.J., McMahon, L.R., De Deurwaerdere, P., Spampinato, U., and Cunningham, K.A. (2003). Selective serotonin reuptake inhibitors enhance cocaine-induced locomotor activity and dopamine release in the nucleus accumbens. Neuropharmacology 44, 342-353.

60. Broderick, P.A., and Phelix, C.F. (1997). Serotonin (5-HT) within dopamine reward circuits signals open-field behavior. Basis for 5-HT-DA interaction in cocaine dysfunctional behavior. Neurosci Biobehav Rev 21, 227-260.

61. Piazza, P.V., Deroche-Gamonent, V., Rouge-Pont, F., and Le Moal, M. (2000). Vertical shifts in self-administration dose-response functions predict a drug-vulnerable phenotype predisposed to addiction. J Neurosci 20, 4226-4232.

62. Belin, D., Mar, A.C., Dalley, J.W., Robbins, T.W., and Everitt, B.J. (2008). High impulsivity predicts the switch to compulsive cocaine-taking. Science 320, 1352-1355.

63. Ranaldi, R., Bauco, P., McCormick, S., Cools, A.R., and Wise, R.A. (2001). Equal sensitivity to cocaine reward in addiction-prone and addiction-resistant rat genotypes. Behav Pharmacol 12, 527-534.

64. Mantsch, J.R., Ho, A., Schlussman, S.D., and Kreek, M.J. (2001). Predictable individual differences in the initiation of cocaine self-administration by rats under extended-access conditions are dose-dependent. Psychopharmacology (Berl) 157, 31-39. 


\section{Main document}

65. Davis, B.A., Clinton, S.M., Akil, H., and Becker, J.B. (2008). The effects of noveltyseeking phenotypes and sex differences on acquisition of cocaine self-administration in selectively bred High-Responder and Low-Responder rats. Pharmacol Biochem Behav 90, 331-338.

66. Kabbaj, M., Norton, C.S., Kollack-Walker, S., Watson, S.J., Robinson, T.E., and Akil, H. (2001). Social defeat alters the acquisition of cocaine self-administration in rats: role of individual differences in cocaine-taking behavior. Psychopharmacology (Berl) 158, 382387.

67. Piazza, P.V., Deminiere, J.M., Le Moal, M., and Simon, H. (1989). Factors that predict individual vulnerability to amphetamine self-administration. Science 245, 1511-1513.

68. Hooks, M.S., Jones, D.N., Holtzman, S.G., Juncos, J.L., Kalivas, P.W., and Justice, J.B., Jr. (1994). Individual differences in behavior following amphetamine, GBR-12909, or apomorphine but not SKF-38393 or quinpirole. Psychopharmacology (Berl) 116, 217-225.

69. Bevins, R.A., and Peterson, J.L. (2004). Individual differences in rats' reactivity to novelty and the unconditioned and conditioned locomotor effects of methamphetamine. Pharmacol Biochem Behav 79, 65-74.

70. Cools, A.R., Ellenbroek, B.A., Gingras, M.A., Engbersen, A., and Heeren, D. (1997). Differences in vulnerability and susceptibility to dexamphetamine in Nijmegen high and low responders to novelty: a dose-effect analysis of spatio-temporal programming of behaviour. Psychopharmacology (Berl) 132, 181-187.

71. Klebaur, J.E., Bevins, R.A., Segar, T.M., and Bardo, M.T. (2001). Individual differences in behavioral responses to novelty and amphetamine self-administration in male and female rats. Behav Pharmacol 12, 267-275.

72. Maurice, T., Martin-Fardon, R., Romieu, P., and Matsumoto, R.R. (2002). Sigma(1) (sigma(1)) receptor antagonists represent a new strategy against cocaine addiction and toxicity. Neurosci Biobehav Rev 26, 499-527.

73. Minabe, Y., Matsuno, K., and Ashby, C.R., Jr. (1999). Acute and chronic administration of the selective sigma1 receptor agonist SA4503 significantly alters the activity of midbrain dopamine neurons in rats: An in vivo electrophysiological study. Synapse 33, 129-140.

74. Bermack, J.E., and Debonnel, G. (2001). Modulation of serotonergic neurotransmission by short- and long-term treatments with sigma ligands. Br J Pharmacol 134, 691-699.

75. Bari, A., Theobald, D.E., Caprioli, D., Mar, A.C., Aidoo-Micah, A., Dalley, J.W., and Robbins, T.W. (2010). Serotonin modulates sensitivity to reward and negative feedback in a probabilistic reversal learning task in rats. Neuropsychopharmacology 35, 1290-1301.

76. Uhl, G.R., Hall, F.S., and Sora, I. (2002). Cocaine, reward, movement and monoamine transporters. Mol Psychiatry 7, 21-26. 


\section{Main document}

Figures and legends

a

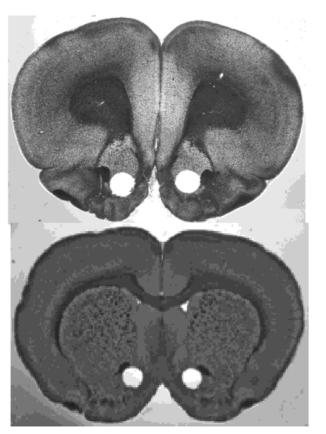

C

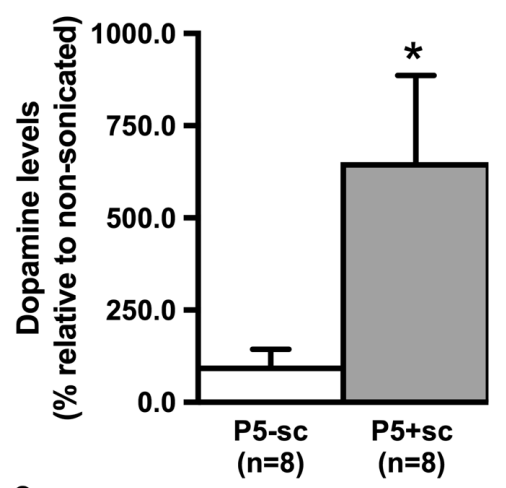

e

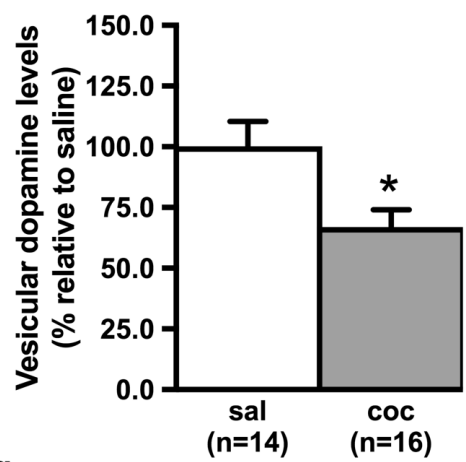

g

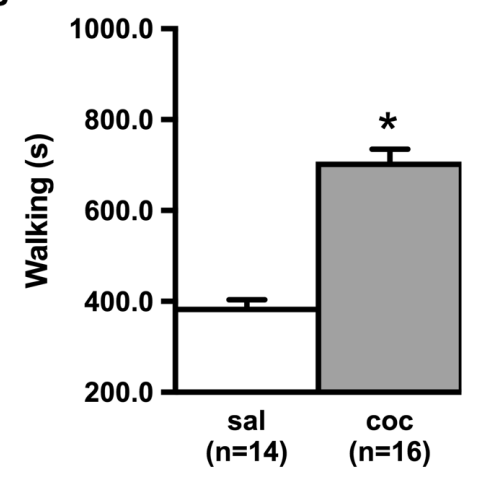

b

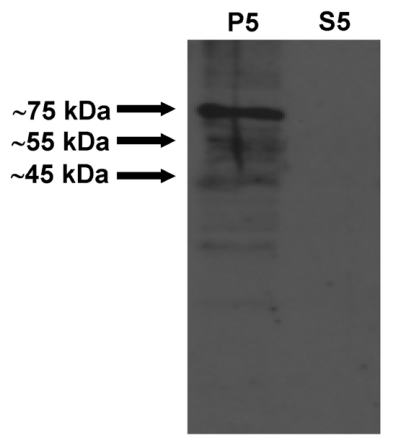

d

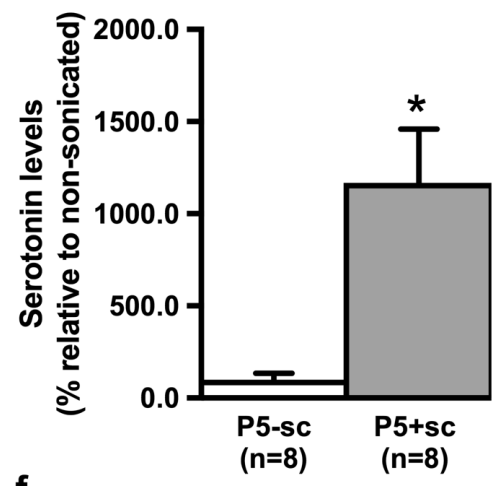

f

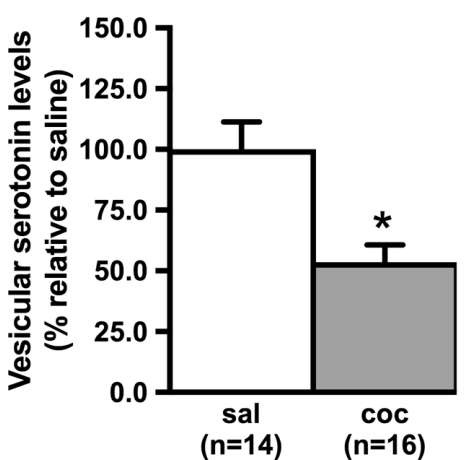

h

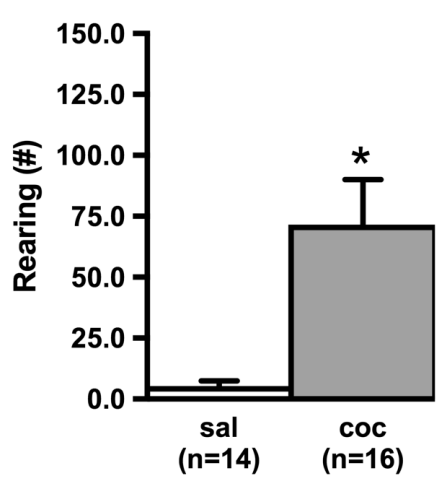

\begin{tabular}{|c|c|c|}
\hline & $\begin{array}{c}\text { Cocaine-induced } \\
\text { walking }\end{array}$ & $\begin{array}{c}\text { Cocaine-induced } \\
\text { repetitive rearing }\end{array}$ \\
\hline $\begin{array}{c}\text { Vesicular dopamine } \\
\text { levels }\end{array}$ & $\begin{array}{c}\mathrm{R}=-\mathbf{0 . 6 6 6 ,} \\
\mathrm{p}<0.01\end{array}$ & n.s. \\
\hline $\begin{array}{c}\text { Vesicular serotonin } \\
\text { levels }\end{array}$ & n.s. & $\begin{array}{c}\mathrm{R}=-\mathbf{0 . 5 1 0} \\
\mathrm{p}<0.05\end{array}$ \\
\hline
\end{tabular}

Figure 1 
bioRxiv preprint doi: https://doi.org/10.1101/651505; this version posted May 27, 2019. The copyright holder for this preprint (which was not certified by peer review) is the author/funder. All rights reserved. No reuse allowed without permission.

Main document

407 Fig. 1: Cocaine (COC) results in vesicular monoamine release that is correlated with changes

408 in walking and rearing behavior. Ultracentrifugation was used to isolate the monoaminergic 409 storage vesicles of the rat nucleus accumbens (a) and Western blot analysis revealed various 410 glycosylated forms of vesicular monoamine transporters type 2 (VMAT-2) in vesicular pellet P5, 411 but not in its supernatant S5 (b). The vesicular pellet P5 and its supernatant S5 resulted from the 412 ultracentrifugation of supernatant $\mathrm{S} 4$ at $100000 \mathrm{~g}$ for $45 \mathrm{~min}$ (for details: see Supplemental 413 Materials and Methods)._Sonication (sc) of the re-suspended pellet P5 leads to the liberation of 414 dopamine (DA) (c) and serotonin (5-HT) (d) from the isolated storage vesicles, and systemic 415 administration of COC depletes these vesicles as demonstrated by a COC-induced reduction in the 416 intra-vesicular levels of DA (e) and 5-HT (f). Systemic administration of COC also changed 417 walking (g) and rearing (h). The COC-induced depletion of the dopaminergic storage vesicles of 418 the nucleus accumbens significantly correlated with an increase in COC-induced walking, but not 419 rearing (i). In contrast, the COC-induced depletion of the serotonergic storage vesicles of the 420 nucleus accumbens significantly correlated with an increase in COC-induced rearing, but not 421 walking (i). *Significant difference between sonicated (+sc) and non-sonicated (-sc) P5 vesicular 422 fraction or between saline (sal)- and COC-treated rats (one-way ANOVA: $\mathrm{p}<0.05$ ). All data are 423 expressed as mean \pm SEM. 
Main document

a

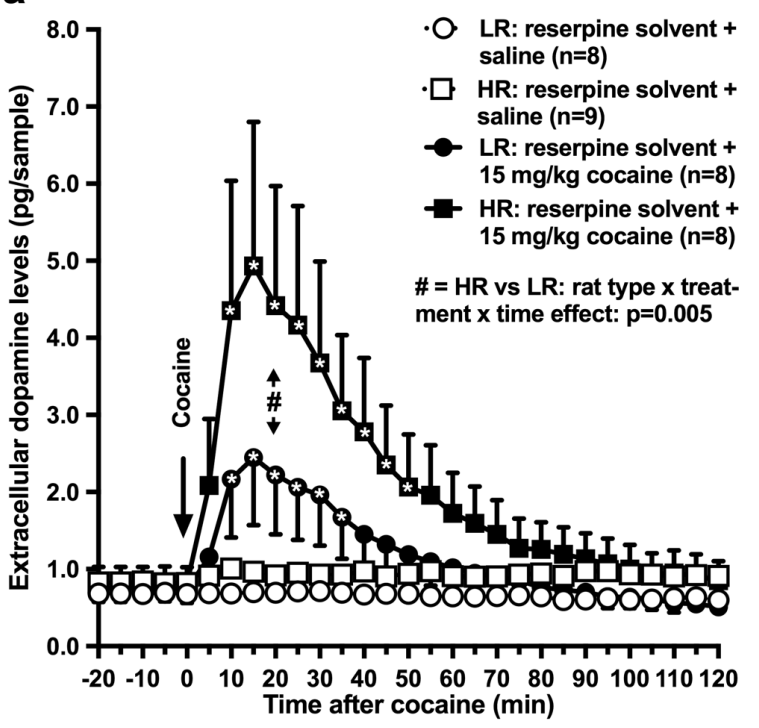

b

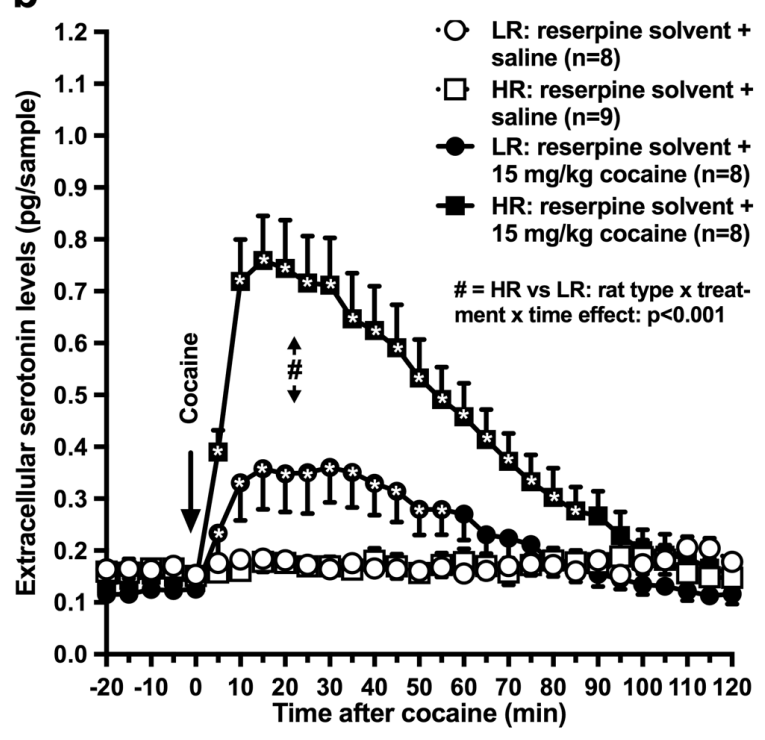

C

\begin{tabular}{|c|c|c|}
\hline & $\begin{array}{c}\text { Distance on open } \\
\text { field }\end{array}$ & $\begin{array}{c}\text { Habituation time } \\
\text { on open field }\end{array}$ \\
\hline $\begin{array}{c}\text { Maximum cocaine-induced extracellular } \\
\text { dopamine increase }\end{array}$ & $\mathrm{R}=0.510$, & $\mathrm{R}=0.564$, \\
$\mathrm{p}<0.05$ & $\mathrm{p}<0.05$ \\
\hline $\begin{array}{c}\text { Maximum cocaine-induced extracellular } \\
\text { serotonin increase }\end{array}$ & $\mathrm{R}=0.675$, & $\mathrm{R}=0.561$, \\
$\mathrm{p}<0.01$ & $\mathrm{p}<0.05$ \\
\hline
\end{tabular}

d

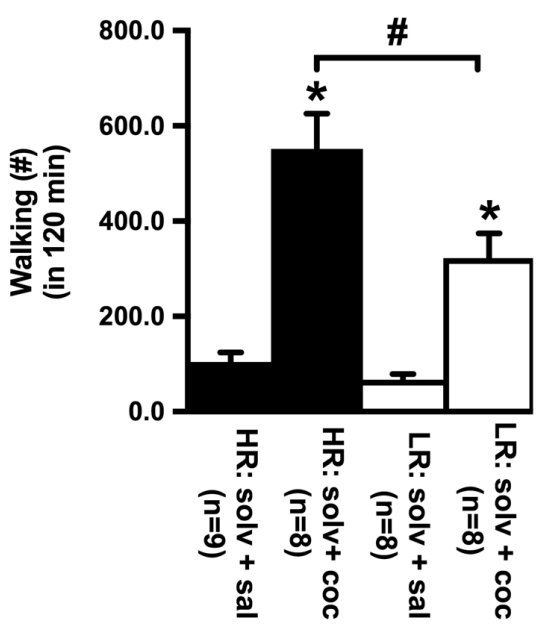

e

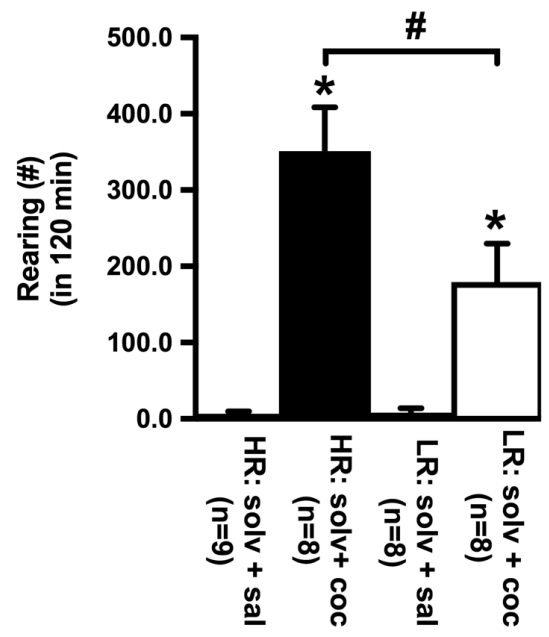

\section{f}

\begin{tabular}{|c|c|c|}
\hline & $\begin{array}{c}\text { Cocaine-induced } \\
\text { walking }\end{array}$ & $\begin{array}{c}\text { Cocaine-induced } \\
\text { rearing }\end{array}$ \\
\hline $\begin{array}{c}\text { Maximum cocaine-induced extracellular } \\
\text { dopamine increase }\end{array}$ & $\begin{array}{c}\mathrm{R}=0.489, \\
\mathrm{p}=0.05\end{array}$ & $\begin{array}{c}\mathrm{R}=0.583, \\
\mathrm{p}<0.05\end{array}$ \\
\hline $\begin{array}{c}\text { Maximum cocaine-induced extracellular } \\
\text { serotonin increase }\end{array}$ & $\begin{array}{c}\mathrm{R}=0.646, \\
\mathrm{p}<0.01\end{array}$ & $\begin{array}{c}\mathrm{R}=0.591, \\
\mathrm{p}<0.05\end{array}$ \\
\hline
\end{tabular}

Figure 2 
bioRxiv preprint doi: https://doi.org/10.1101/651505; this version posted May 27, 2019. The copyright holder for this preprint (which was not certified by peer review) is the author/funder. All rights reserved. No reuse allowed without permission.

Main document

424 Fig. 2: Individual differences in monoamine and behavioral responses to cocaine (COC).

425 Systemic administration of COC increases the extracellular levels of accumbal dopamine (DA) (a)

426 and serotonin (5-HT) (b) more strongly in High Responder to novelty (HR) than in Low Responder

427 to novelty (LR) rats, and the maximum COC-induced increase in the extracellular levels of these

428 monoamines was found to correlate significantly with the distance travelled and habituation time

429 used to select these animals on the open-field (c). Significant COC-induced monoamine

430 increase relative to saline (Student's t-test: $\mathrm{p}<0.05$ ). "Significant difference between HR and LR

431 (multi-way ANOVA: $\mathrm{p} \leq 0.005)$. COC also increased the frequency of walking (d) and rearing (e)

432 more strongly in HR than in LR. The observed COC-induced increase in the extracellular levels

433 of DA and 5-HT correlated with the increase in COC-induced walking and rearing (f). *Significant

434 difference between COC and saline (sal), and " significant difference between HR and LR (one-

435 way ANOVA: $\mathrm{p}<0.05)$. Correlation analysis was performed in the pooled group of HR and LR.

436 All rats were pre-treated with the solvent (solv) or reserpine (RES). All data are expressed as mean

$437 \pm$ SEM. 
Main document
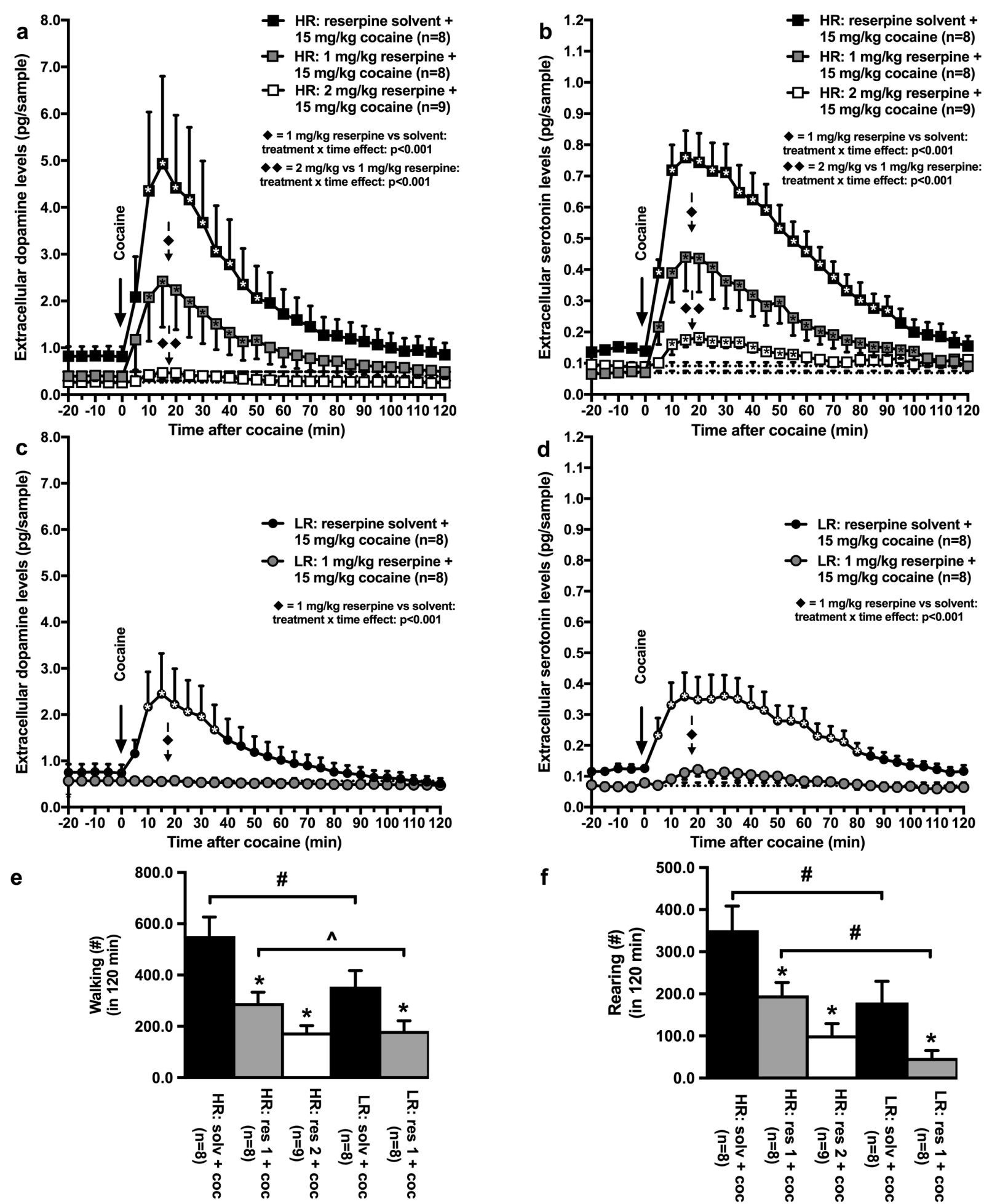

f

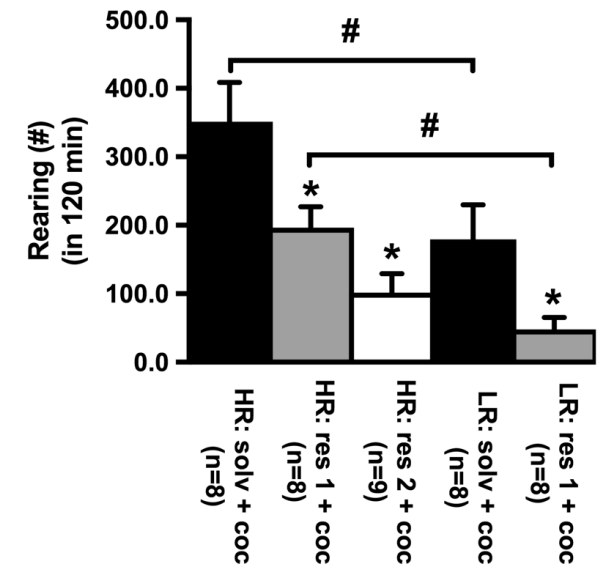

g

\begin{tabular}{|c|c|c|}
\hline & $\begin{array}{c}\text { Cocaine-induced walking } \\
\text { after reserpine }\end{array}$ & $\begin{array}{c}\text { Cocaine-induced rearing } \\
\text { after reserpine }\end{array}$ \\
\hline $\begin{array}{c}\text { Maximum reserpine-induced extracellular } \\
\text { dopamine decrease }\end{array}$ & $\begin{array}{c}\mathrm{R}=-0.534, \\
\mathrm{p}<0.05\end{array}$ & $\mathrm{n.s.}$ \\
\hline $\begin{array}{c}\text { Maximum reserpine-induced extracellular } \\
\text { serotonin decrease }\end{array}$ & $\mathrm{n.s.}$ & $\begin{array}{c}\mathrm{R}=-0.531, \\
\mathrm{p}<0.05\end{array}$ \\
\hline
\end{tabular}

Figure 3 
bioRxiv preprint doi: https://doi.org/10.1101/651505; this version posted May 27, 2019. The copyright holder for this preprint (which was not certified by peer review) is the author/funder. All rights reserved. No reuse allowed without permission.

Main document

Fig. 3: Monoaminergic storage vesicles control individual differences in monoamine and behavioral responses to cocaine (COC). Reserpine (RES) reduced the COC-induced increase in accumbal extracellular dopamine (DA) and serotonin (5-HT) levels in both High Responder to novelty (HR) (a/b) and Low Responder to novelty (LR) (c/d) rats. However, COC could still

442 increase the accumbal extracellular monoamine levels in HR, but not anymore in LR, that were 443 treated with $1 \mathrm{mg} / \mathrm{kg}$ of the vesicle depleting agent. 444 increase relative to baseline (one-sample t-tests: $\mathrm{p}<0.05$ ). $\diamond$ Significant RES-induced monoamine 445 reduction, and $\diamond$ significant RES dose effect (multi-way ANOVA: $p<0.05$ ). RES also reduced 446 the COC-induced increase in walking and rearing in HR and in LR (e/f). *Significant decrease 447 after RES (one-way ANOVA: $\mathrm{p}<0.05$ ). "Significant difference between HR and LR (one-way 448 ANOVA: $\mathrm{p}<0.05$ ). ^ Trend towards significant difference between HR and LR (one-way ANOVA: $449 \mathrm{p}<0.075)$. The observed RES-induced reduction in the extracellular levels of DA was significantly 450 correlated with the decrease in walking, but not rearing (g), whereas the observed RES-induced 451 reduction in the extracellular levels of 5-HT was significantly correlated with the decrease in 452 rearing, but not walking (g). Correlation analysis was performed in the pooled group of HR and 453 LR treated with $1 \mathrm{mg} / \mathrm{kg}$ of RES. All data are expressed as mean $\pm \mathrm{SEM}$. 


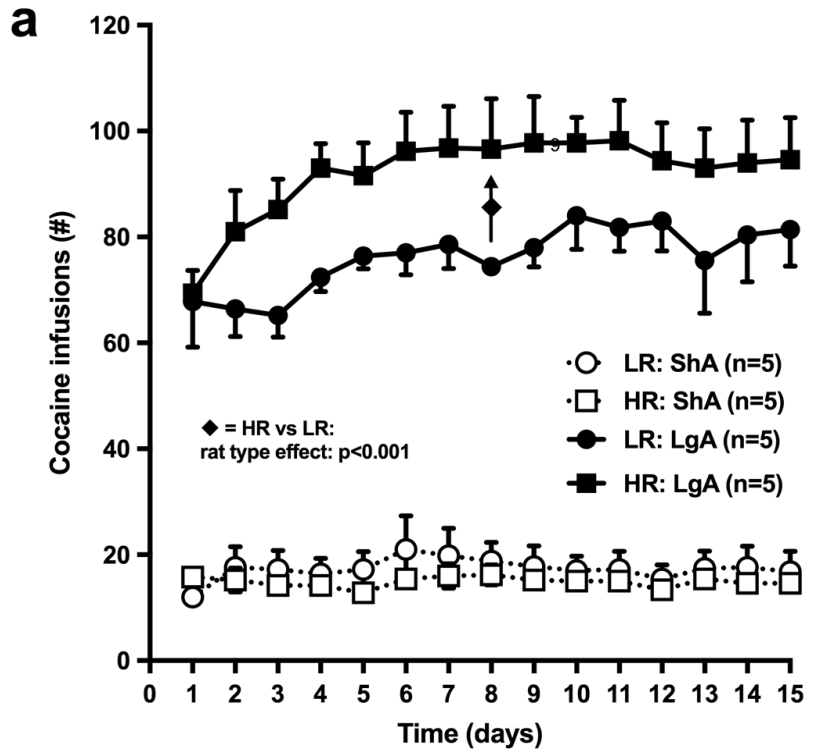

\begin{tabular}{|c|c|c|}
\hline & $\begin{array}{c}\text { Distance on open } \\
\text { field }\end{array}$ & $\begin{array}{c}\text { Habituation time } \\
\text { on open field }\end{array}$ \\
\hline Long access cocaine intake & $\begin{array}{c}\mathrm{R}=0.712, \\
p<0.05\end{array}$ & $\begin{array}{c}\mathrm{R}=0.747, \\
\mathrm{p}<0.05\end{array}$ \\
\hline Short access cocaine intake & $\begin{array}{c}\mathrm{R}=0.669, \\
\mathrm{p}<0.05\end{array}$ & $\begin{array}{c}\mathrm{R}=0.683, \\
\mathrm{p}<0.05\end{array}$ \\
\hline
\end{tabular}

Figure 4

454 Fig. 4: Individual differences in cocaine (COC) self-administration. Short Access (ShA) and

455 Long Access (LgA) voluntary COC self-administration (a) correlated positively with the

456 locomotor response to novelty (b). Significant rat type effect (multi-way ANOVA: $<<0.05$ ).

457 Correlation analysis was performed in a pooled group of High Responder to novelty (HR) and

458 Low Responder to novelty (LR) rats. All data are expressed as mean $\pm \mathrm{SEM}$. 
Main document
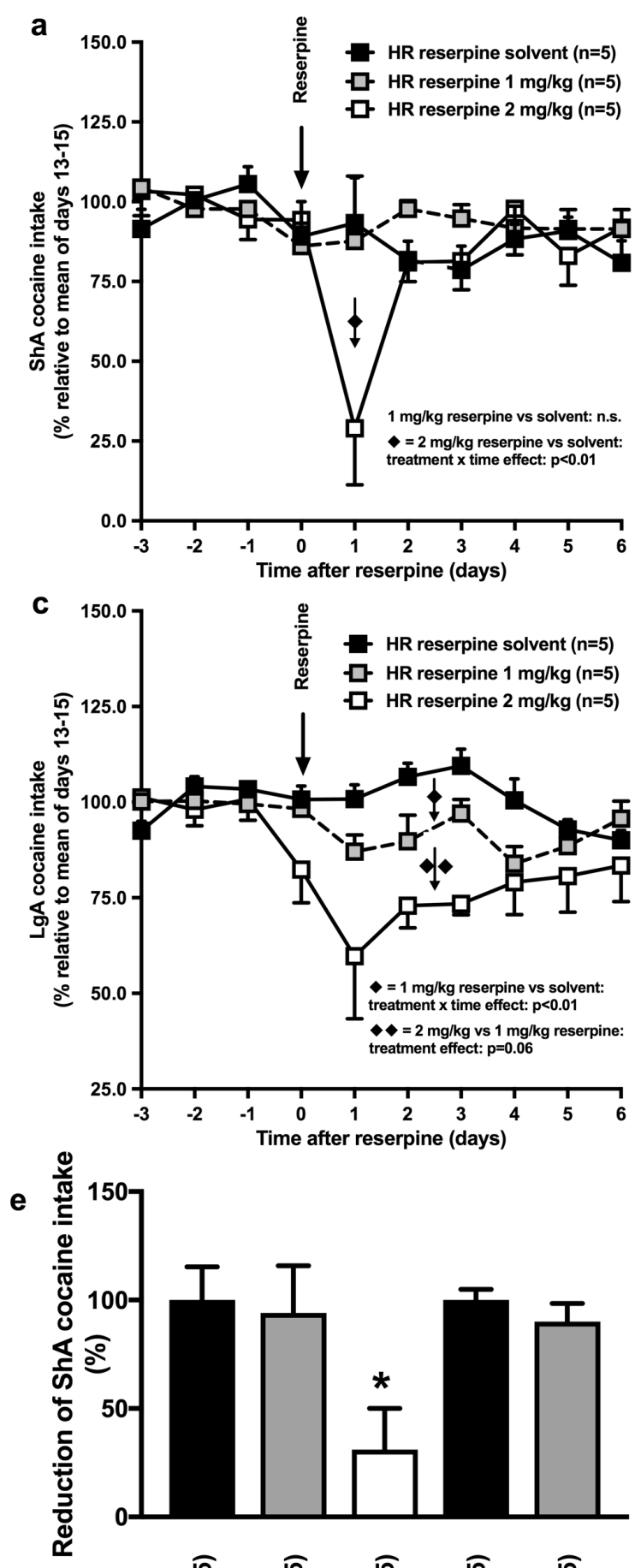

g b
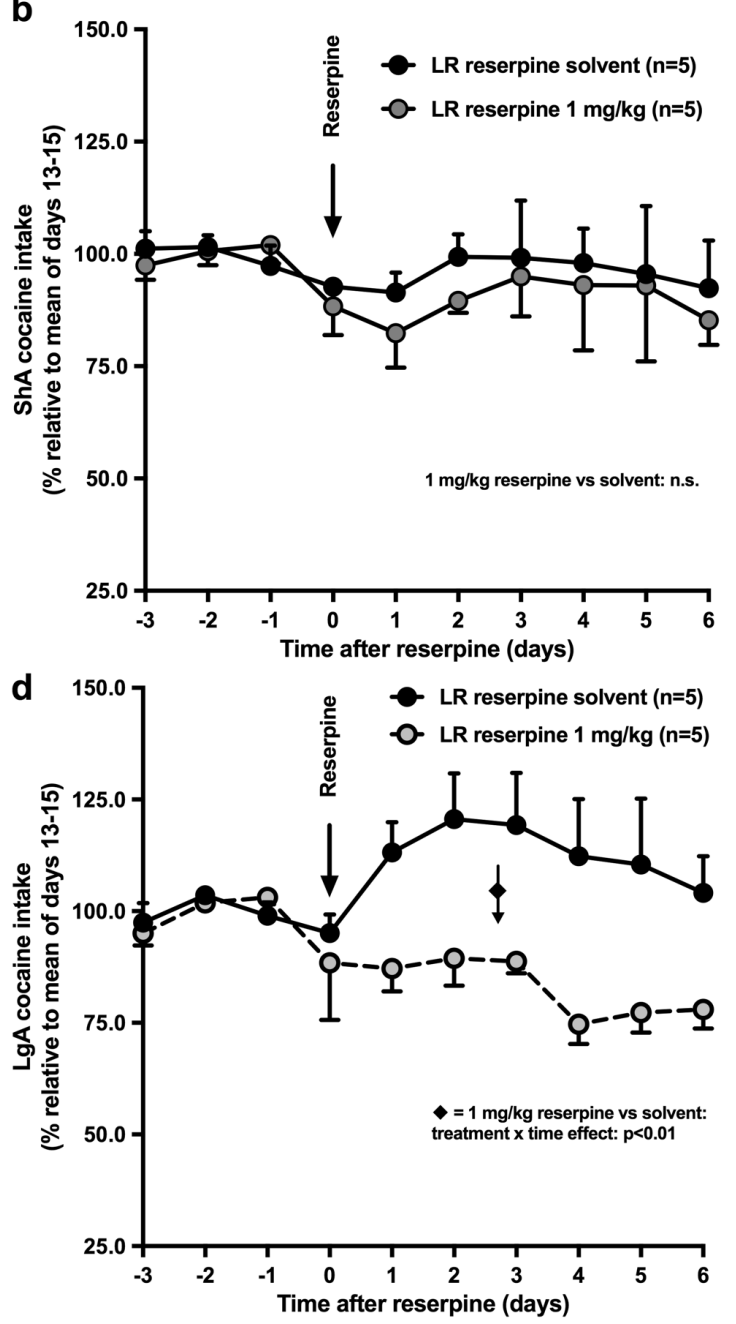

$f$

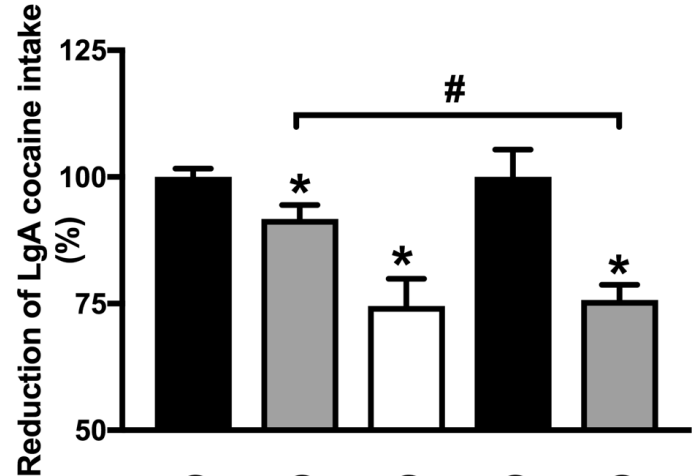

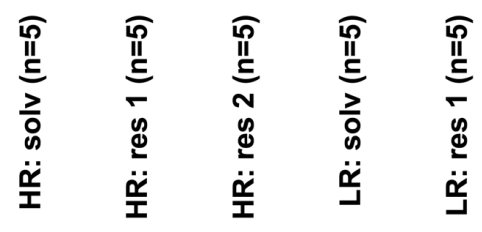

\begin{tabular}{|c|c|c|}
\hline & $\begin{array}{c}\text { Distance on open } \\
\text { field }\end{array}$ & $\begin{array}{c}\text { Habituation time } \\
\text { on open field }\end{array}$ \\
\hline $\begin{array}{c}\text { Maximum reserpine-induced reduction of } \\
\text { ShA cocaine intake }\end{array}$ & n.s. & n.s. \\
\hline $\begin{array}{c}\text { Maximum reserpine-induced reduction of } \\
\text { LgA cocaine intake }\end{array}$ & $\begin{array}{c}\mathrm{R}=-\mathbf{0 . 6 8 4} \\
\mathrm{p}<0.05\end{array}$ & $\begin{array}{c}\mathrm{R}=-0.845, \\
\mathrm{p}<0.01\end{array}$ \\
\hline
\end{tabular}

Figure 5 
bioRxiv preprint doi: https://doi.org/10.1101/651505; this version posted May 27, 2019. The copyright holder for this preprint (which was not certified by peer review) is the author/funder. All rights reserved. No reuse allowed without permission.

Main document

459

460

461

462

463 464 the LgA, but also the ShA, COC intake (a/c).

465

466

467

468

469

470

471

472

473

Fig. 5: Monoaminergic storage vesicles control individual differences in cocaine (COC) selfadministration. Reserpine (RES), $1 \mathrm{mg} / \mathrm{kg}$, did not affect voluntary COC self-administration under Short Access (ShA) conditions (a/b). However, this low dose of the vesicle depleting agent reduced the Long Access $(\operatorname{LgA})$ self-administation of the psychostimulant (c/d).

Significant RES-induced reduction in the COC intake. The higher dose $(2 \mathrm{mg} / \mathrm{kg})$ of RES reduced not only significant RES dose effect (multi-way ANOVA: $\mathrm{p}<0.05$ ). The smaller RES-sensitive storage capacity in LR versus HR rats (see Supplemental Fig. S2) is in line with LR rats being more sensitive to RES-induced vesicle depletion than HR rats (e/f). *Significant decrease after RES (one-way ANOVA: $\mathrm{p}<0.05$ ). \#Significant difference between HR and LR (one-way ANOVA: $p<0.05$ ). A low locomotor response to novelty correlated with a strong RES-induced reduction in the LgA COC intake (g). Correlation analysis was performed in the pooled group of HR and LR. Note: panels e and $f$ represent the mean COC intake after RES treatment expressed as a percentage of the mean COC intake after treatment with RES solvent. $1 \mathrm{mg} / \mathrm{kg}$ of RES reduced the mean $\mathrm{LgA}$ intake of COC by $25 \%$ in LR and $10 \%$ in HR. All data are expressed as mean \pm SEM. 